\title{
Potential of Differential Somatic Cell Counts as Indicators of Mastitis in Quarter Milk Samples from Dairy Cows
}

\author{
By Ulf Emanuelson and Paul Wever
}

Swedish Association for Livestock Breeding and Production, Eskilstuna, and Department of Animal Breeding and Genetics, Swedish University of Agricultural Sciences, Uppsala, Sweden.

\begin{abstract}
Emanuelson, $U$ and $P$. Wever: Potential of differential somatic cell counts as indicators of mastitis in quarter milk samples from dairy cows. Acta vet. scand. 1989, 30, 475-481. - Bacteriological status, somatic cell counts and proportions of lymphocytes, granulocytes and monocytes were determined in 1,659 quarter milk samples from 39 dairy cows. Discriminant analysis was performed in order to assess the ability of total and differential somatic cell counts and combinations of total somatic cell count and each of the differential cell counts, to discriminate between infected and pathogen-free quarters, as well as between quarters infected with minor pathogens and quarters infected with major pathogens. Total somatic cell count classified $82.9 \%$ of all quarters correctly with respect to bacteriological status. Differential somatic cell count was less effective than total somatic cell count in discriminating between infected and pathogen-free quarters, as well as between quarters infected with minor vs. major pathogens. Combination of total and differential somatic cell counts did not improve the rate of correctly classified quarters. Inclusion of demographic data into the discriminant function increased the number of quarters correctly classified, mainly through an increase in the proportion of correctly classified infected quarters.
\end{abstract}

dıscrıminant analysis; bacteriology; leukocyte; bovıne mastıtis

\section{Introduction}

Mastitis is generally thought to be the most costly disease of dairy cattle. The financial losses are chiefly attributable to direct milk losses, discarded milk, treatment of clinical cases and culling of animals. From an economic point of view, but also from an ethical one, it must be of great value to reduce the incidence of mastitis. To achieve this, it is necessary to identify the health status of individual cows. Many parameters have been tested for suitability as indicators of mastitis, e.g. somatic cell counts, adenosine triphosphate, $\quad N$-acetyl- $\beta$ - $D$-glucosaminidase, bovine serum albumin, antitrypsin, electrical conductivity, and lactose content (e.g. Renner 1975, Honkanen-Buzalski \& Sand- holm 1981, Fernando et al. 1982, Sheldrake et al. 1983a, Emanuelson et al. 1987, Heuven 1987). The somatic cell count (SCC) has so far been the most widely used parameter and it is an established and reliable procedure well adapted for mass analyses.

One source of information that may supplement the SCC in indicating mastitis is the proportional distribution of different cell populations, i.e. the differential cell count, since it is known to change upon infection. It is generally agreed that the predominant cell type in milk from healthy cows is the monocyte (Lee et al. 1980, McDonald \& Anderson 1981, Fox et al. 1985) and that large numbers of polymorph nuclear neutrophils enter the mammary gland when it becomes infected 
(Jain et al. 1971, Jain 1976, Paape et al. 1979).

The differential somatic cell count (DCC) has been investigated earlier with respect to its usefulness in discriminating between healthy and mastitic quarters and cows (Blackburn et al. 1955, Sheldrake et al. 1977, Hoare et al. 1980, Meek et al. 1980, Dohoo et al. 1981), but the results have been rather variable. However, the differential cell count used in most studies has been based on cell volume distribution, which does not give a true differentiation in different cell types. Improved equipment, giving a more accurate and rapid differentiation between cell populations, and a drop in price of such equipment, has led to a renewed interest in differential somatic cell counting for use in field applications.

The objective of the present study was to investigate the possible advantages of using the DCC as mastitis indicator over the use of total SCC only. The value of including demographic variables in the discrimination process was also investigated.

\section{Materials and methods}

Total somatic cell counts (SCC) and differential somatic cell counts (DCC) were determined in 1,659 quarter milk samples with confirmed bacteriological status. The milk samples originated from 39 dairy cows sampled at weekly intervals during 2 periods (November 1981-June 1982 an October 1982-May 1983). SCC and DCC were determined with the two-colour flowcytometry method as described by Hageltorn \& Saad (1986). The SCC was measured in 1000 cells per $\mathrm{ml}$ and transformed to a log scale with base 10 (LSCC) in order to normalize the distribution. The DCC was the proportion (\%) of lymphocytes, granulocytes and monocytes in the total cell population (denoted as LYM\%, GRAN\% and MON\%, respective- ly). Samples were classified according to their bacteriological status as pathogen-free (NI), infected with minor pathogens (MIP), or infected with major pathogens (MAP). Further details on material and methods can be found in Wever \& Emanuelson (1989).

Discriminant analyses were performed in order to determine how well LSCC, GRAN\%, MON\% and LYM\% and combinations of LSCC with each of the DCC discriminated between infected (MIP and MAP) and pathogen-free (NI) quarters and also between MIP and MAP quarters. The effect of including somatic cell counts and differential cell counts taken 1 and 2 weeks previous to LSCC and DCC (LSCC1, LSCC2, LYM1\%, LYM $2 \%$, GRAN1\%, etc.) in the discriminant function was also studied. Since it is well known that LSCC - and, to a lesser extent DCC - are affected by systematic influences (e.g. Wever \& Emanuelson 1989), the effect of including demographic variables (parity, stage of lactation, period of sampling and month of sampling) in the discriminant function in addition to LSCC and DCC was studied as well. The discriminative potential was scored as the percentage of samples in each bacteriological group that was correctly classified and the overall percentage of samples that was correctly class1fied. All discriminant analyses were performed with the procedure DISCRIM of SAS (SAS Institute Inc. 1985).

\section{Results}

Overall means and standard deviations for LSCC and DCC for the different bacteriological classes are given in Table 1. MAP samples had highest, NI samples lowest and MIP samples intermediate LSCC. The major cell type in NI samples was the monocyte, whereas the granulocyte was predominant in both MIP and MAP samples. The lymphocyte was the least frequent cell type in all 
Table 1. Number of observations $(N)$, means $(\bar{x})$ and standard deviations (SD) for log somatic cell counts (LSCC) and proportions of lymphocytes (LYM\%), granulocytes (GRAN\%) and monocytes (MON\%) in groups of quarter milk samples with known bacteriological status ${ }^{1}$.

\begin{tabular}{|c|c|c|c|c|c|c|c|c|c|}
\hline \multirow{2}{*}{$\begin{array}{l}\text { Group of } \\
\text { samples }\end{array}$} & \multirow[b]{2}{*}{$\mathrm{N}$} & \multicolumn{2}{|c|}{ LSCC } & \multicolumn{2}{|c|}{ LYM\% } & \multicolumn{2}{|c|}{ GRAN\% } & \multicolumn{2}{|c|}{ MON\% } \\
\hline & & $\overline{\mathbf{x}}$ & $\mathrm{SD}$ & $\overline{\bar{x}}$ & $\overline{\mathrm{SD}}$ & $\overline{\bar{x}}$ & $\overline{\mathrm{SD}}$ & $\overline{\mathrm{y}}$ & SD \\
\hline ALL & 1659 & 2.4 & .6 & 15.9 & 10.4 & 39.2 & 160 & 448 & 17.7 \\
\hline NI & 1249 & 2.2 & .4 & 15.2 & 10.1 & 368 & 15.8 & 48.0 & 151 \\
\hline I & 410 & 3.0 & .6 & 18.1 & 11.0 & 46.7 & 16.3 & 35.2 & 16.7 \\
\hline MIP & 338 & 2.9 & .5 & 18.2 & 10.9 & 465 & 15.5 & 35.3 & 15.0 \\
\hline MAP & 72 & 3.6 & .6 & 17.4 & 11.5 & 478 & 218 & 34.9 & 21.2 \\
\hline
\end{tabular}

' Sce main text for description of groups of quarter milk samples.

groups, although somewhat more common in infected samples.

No discrimination between MIP and MAP samples was obtained with any of the DCC variables: all samples were classified as MIP. LSCC, however, discriminated between MIP and MAP samples with an overall classification rate of $86 \%$, while $96 \%$ and $38 \%$ of MIP and MAP samples, respectively, were classified correctly.

LSCC was superior to each of the DCC in discriminating between infected and pathogen-free samples (Table 2). This was mainly due to a much greater percentage of correctly classified infected samples. None of the combinations of LSCC with DCC yielded a higher overall classification rate than LSCC alone, although the percentage of correctly classified infected samples increased slightly.

Table 2 also gives the effects of including parity, stage of lactation, and period and month of sampling in the discriminant function. The inclusion of these variables increased the proportion of correctly classified infected samples. However, since the majority of the samples $(75 \%)$ were NI, it had little beneficial effect on the overall classification rate.

Combining the LSCC taken on the sampling day with LSCC1 and LSCC2 increased the proportion of correctly classified infected samples, but not the overall classification rate (Table 3). An even larger increase in cor-

T able 2. Proportions (\%) of all samples (overall), pathogen free samples (NI) and infected samples (I) correctly classıfıed by discriminant functions, including total and/or differential somatic cell count variables.

\begin{tabular}{|c|c|c|c|c|c|c|}
\hline \multirow[b]{2}{*}{ Variables ${ }^{1}$} & \multicolumn{3}{|c|}{$\begin{array}{c}\text { Demographic variables } 2 \\
\text { excluded }\end{array}$} & \multicolumn{3}{|c|}{$\begin{array}{c}\text { Demographic variahles } \\
\text { included }\end{array}$} \\
\hline & NI & I & Overall & NI & I & Overall \\
\hline LSCC & 93.9 & 49.5 & 82.9 & 93.4 & 624 & 858 \\
\hline LYM\% & 98.1 & 2.7 & 74.5 & 93.7 & 194 & 754 \\
\hline GRAN\% & 95.5 & 11.7 & 74.8 & 93.3 & 38.8 & 79.9 \\
\hline MON\% & 96.2 & 15.6 & 76.3 & 90.8 & 43.7 & 79.2 \\
\hline LSCC, LYM\% & 93.0 & 51.2 & 82.7 & 92.6 & 62.7 & 853 \\
\hline LSCC, GRAN\% & 93.8 & 49.5 & 82.9 & 92.8 & 62.2 & 85.3 \\
\hline LSCC, MON\% & 93.4 & 49.8 & 82.6 & 92.7 & 65.4 & 86.0 \\
\hline
\end{tabular}

' See main text for description of variables.

2 Demographic variables were parity, stage of lactation, period and month of sampling 
Table 3. Proportions (\%) of all samples (overall), pathogen free samples (NI) and infected samples (I) correctly classified by discriminant functions for combinations of present and previous total and/or differential somatic cell count variables.

\begin{tabular}{lccc}
\hline Variables $^{1}$ & NI & I & Overall \\
\hline LSCC & 93.9 & 49.5 & 82.9 \\
LSCC, LSCC1 & 92.3 & 53.2 & 82.7 \\
LSCC, LSCC1, LSCC2 & 91.3 & 57.3 & 82.7 \\
LSCC, MON\% & 93.4 & 49.8 & 82.6 \\
LSCC, MON\%, LSCC1, MON1\% & 91.5 & 57.1 & 83.0 \\
LSCC, MON\%, LSCC1, MON1\%, LSCC2, MON2\% & 91.2 & 66.1 & 84.9 \\
\hline
\end{tabular}

' See main text for description of variables.

rect classified infected samples was achieved when the combination of LSCC and MON\% was supplemented with LSCC1, MON1\%, LSCC2 and MON2\% (Table 3). Similar results were found for combinations of LSCC and the other DCC variables.

All NI and I quarters were randomly divided into 2 subsets containing 873 and 786 samples respectively, in order to test the discriminant function on a material that was not used to develop the function. Discriminant analyses with LSCC and LSCC plus demographic variables were rerun on the first subset in order to obtain a classification function. This function was subsequently used to classify samples in both the first and the second subset. Overall classification rates with only LSCC in the function were 83.0 and 83.3 for the 2 subsets and the percentages of correctly classified infected samples were 50.7 and 53.9, respectively. These figures were somewhat higher than in the complete dataset (Table 2). Classification rates for the 2 subsets, with LSCC and demographic variables in the function, were also similar to those obtained for the complete dataset.

\section{Discussion}

An indirect differentiation of cells, based on cell volume, has been used in most studies on differential somatic cell counts as mastitis indicator. (Sheldrake et al. 1977, Hoare et al. 1980, Meek et al. 1980, Dohoo et al. 1981). The cell volume class most commonly used in these studies has been shown to consist mainly of neutrophils (Newbould 1978), but neutrophils have also been shown to appear in other cell size classes (Hoare et al. 1980). Consequently the indirect differentiation of cells, based on cell volume, is not very exact and a more accurate differentiation of cells was expected to improve the discrimination of mastitic quarters.

However, this study clearly shows that DCC, i.e. the proportional distribution of different cell populations, was less effective than LSCC in differentiating between infected and pathogen-free samples, as well as between MIP and MAP samples. In contrast, results from Hoare et al. (1980) and Meek et al. (1980) indicated that the differential cell count was more effective in differentiating between infected and pathogenfree quarters than was the total somatic cell count. Hoare et al. (1980) also found a good discrimination, based on either differential or total somatic cell counts, between MIP and MAP quarters in one herd. However, their results were similar to those obtained here, when another herd was studied.

The present results show that very little was gained in overall classification rate by inclu- 
ding DCC in the discriminant function, once LSCC was already included (Table 2), despite a more accurate differentiation of somatic cells. The results closely agree with findings of Blackburn et al. (1955) and Dohoo et al. (1981). Hoare et al. (1980), however, found that the probability of misclassifying quarters decreased if LSCC was supplemented by information on cell volume distribution.

The findings reported earlier by Newbould (1978) and Wever \& Emanuelson (1989) that DCC are to some extent affected by systematic factors, suggest that such factors must be considered when DCC is used to indicate mastitis. This is supported to a degree by the results presented here, showing an increased proportion of correctly classified infected samples when demographic variables are included in the discriminant function (Table 2). However, the increase in overall classification rate was small, which is in agreement with Dohoo et al. (1981) and Sheldrake et al. (1983b).

An increase in the proportion of correctly classified infected quarters was also achieved by incorporating 2 previous weekly LSCC and DCC in the analysis (Table 3). Meek et al. (1980) also showed that it was advantageous to include previous SCC and DCC variables. The inclusion of both demographic and previous cell count data, if available, may result in small improvements. For example, did the inclusion of demographic data in the discriminant function with present and previous LSCC and MON\%, result in an overall classification rate of 86.1 and a proportion of correctly classified infected samples of 70.3, i.e. an increase of 1.2 and 4.2 , respectively.

The results presented here clearly show that the total somatic cell count was superior to DCC as an indicator of mastitis and that the proportional distribution of different cell populations gave little extra information once the total somatic cell count was available. It must be kept in mind, though, that these results refer to only 1 herd and that Hoare et al. (1980) found large differences in classification rates between the 2 herds they studied. It is possible that differences between herds in incidences and in species of bacteria, as well as in the response to similar infections, may affect the comparisons of SCC and DCC. Further studies using the more accurate differentiation of cell populations based on a larger material with several herds is therefore strongly advocated.

The present study concerns the use of total and differential somatic cell counts for diagnostic purposes and SCC is apparently to be favored in this respect. However, DCC may prove to be more valuable for other purposes, such as in breeding for resistance against mastitis. It is conceivable that not only the quantity of cells, but also their functionality, should be taken into account. DCC may be valuable for this purpose, since each cell type has its own more or less specific function in the immune response. DCC may also serve as a valuable tool when different biological processes in the udder are studied, e.g. the involution of the mammary gland and the healing of the udder after a bout of clinical mastitis. More research is needed on differential somatic cell counting and its use for different purposes, in order to obtain full benefit from the information that is contained in it.

\section{References}

Blackburn PS, Laing CM, Malcolm DF: A comparison of the diagnostic value of the total and differential cell counts in bovine milk. J. Dairy Sci. 1955, 22, 36-42.

Dohoo IR, Meek AH, Martin SW, Barnum DA: Use of total and differential somatic cell counts from composite milk samples to detect mastitis in individual cows. Cand. J. comp. Med. 1981, 45, 814. 
Dulın AM, Paape MJ, Weinland BT: Effect of parity, stage of lactation, and intramammary infection on concentration of somatic cells and cytoplasmic particles in goat milk. J. Dairy Sci. 1983, 66, 2426-2433.

Emanuelson $U$, Olsson $T$, Holmberg $O$, Hageltorn $M$, Matılla $T$, Nelson L, Åstrom G. Comparison of some screenıng tests for detectıng mastitıs. J. Dairy Scı. 1987, 70, 880-887.

Emanuelson $U$, Olsson $T$, Mattla $T$, Astrom $G$, Holmberg $O$ : Effects of parity and stage of lactatıon on adenosine triphosphate, somatic cell counts and anti trypsin content in cow's milk. J. Dairy Res. 1988, 55, 49-55.

Fernando $R S$, Rındsıg $R B$ \& Spahr SL: Electrical conductıvity of milk for detectıng mastitis. J. Dairy Sci. 1982, 65, 659-664.

Fox LK, Shook GE, Schultz LH: Factors related to milk loss in quarters with low somatic cell counts. J. Dairy Sc1. 1985, 68, 2100-2107.

Hageltorn M, Saad AM: Flow cytofluorometric characterization of bovine blood and milk leukocytes. Amer. J. vet. Res. 1986, 47, 2012-2016.

Heuven HCM: Diagnostic and genetic analysis of mastitis field data. Thesis in partial fulfilment of the requirements for the degree of Ph. D., University of Wisconsin, Madison, WI, USA 1987.

Hoare RJT, Sheldrake PJN, McGregor GD, Woodhouse $E W$ : Somatic cell volume distribution as an ard to the dragnosis of mastitis. J. Darry Res. 1980, 47, 167-176.

Honkanen-Buzalski T, Sandholm M: Trypsin-inhibitors in mastitic milk and colostrum: correlation between trypsın-ınhibitor capacity, bovine serum albumin and somatic cell contents. J. Dairy Res. 1981, 48, 213-223.

Jain NC: Neutrophil leucocytes and inflamation of the bovine mammary gland. Theriogenology 1976, 6, 153-173.

Jain NC, Schalm DW, Lasmanis J: Experimentally induced coliform (Aerobacter aerogenes) mastitis in normal cows and cows made neutrophenic by an equine ant1-bovine leucocyte serum. Amer. J. vet. Res. 1971, 32, 1929-1935.

Kennedy $B W$, Sethar MS, Tong AKW, Moxley JE, Downey BR: Environmental factors influencing test-day somatic cell counts in Holsteins. J. Dairy Sci. 1982, 65, 275-280.
Lee Ch, Woodıng FBP, Kemp P: Identification, properties and differential counts of cell populations using electron microscopy of dry cows secretions, colostrum and milk from normal cows. J. Dairy Res. 1980, 47, 39-50.

McDonald JS, Anderson AJ: Total and differential somatic cell counts in secretions from noninfected bovine mammary glands: The peripartum period. Amer. J. vet. Res. 1981, 42, 1366-1370.

Meek AH, Barnum DA, Newbould FHS: Use of total and differential somatic cell counts to differentiate potentially infected from potentially non-infected quarters and cows and between herds of various levels of infection. J. Food Prot. 1980, 43, 10-14.

Newbould FHS: Effect of several factors on differential countıng of somatic cells in farm bulk tank milk. J. Food Prot. 1978, 41, 96-99.

Paape MJ, Wergın AJ, Guıdry AJ, Pearson RE: Leucocytes - second line of defence against invading mastitis pathogens. J. Dairy Sci. 1979, 62, 135-153.

Renner $E$ : Investigations on some parameters of the milk for detection of subclinical mastitis. Proceedings of Seminar on Mastitis Control, 1975, IDF Bulletin 85.

SAS Institute Inc.: The DISCRIM procedure. SAS user's guide: Statistics. SAS Institute Inc., Cary, N.C., USA 1985.

Schulze WD, Bramley AJ: Effect of Escherichia colı endotoxin-mediated inflammation of one mammary quarter of the bovine udder on diapedesis into other quarters. J. Dairy Res. 1982, 49, 381385.

Sheldrake RF, Hoare RJT, Woodhouse VE, McGregor GD: Cell volume to aid analysis and technique of somatic cell counts in milk. J. Dairy Sci. 1977, 60, 882-888.

Sheldrake RF, McGregor GD, Hoare RJT: Somatic cell count, electrical conductivity, and serum albumin concentration for detecting bovine mastitis. J. Dairy Sci. 1983a, 66, 548-555.

Sheldrake RF, Hoare RJT, McGregor GD: Lactation stage, parity, and infection affecting somatic cell counts, electrical conductivity and serum albumin in milk. J. Dairy Sci. 1983b, 66, 542547. 
Wever P, Emanuelson $U$ : Effects of systematic influences and intramammary infection on differential and total somatic cell counts in quarter milk samples from dairy cows. Acta vet. scand. $1989,30,465-474$.

\section{Sammandrag}

Differentıerad cellhalt som ındıkator på mastıt l Juverfjardedelsprov.

Bakteriologisk status, total cellhalt samt proportion lymfocyter, granulocyter och monocyter (differentierad cellhalt), bestamdes 11659 juverfjardedelsprov från 39 kor. Formågan hos total och differentıerad cellhalt, enskilda och 1 kombınation, att skilja dels mellan infekterade och 1cke infekterade juverdelar och dels mellan juverdelar infekterade med hog- patogena och lågpatogena bakterier skattades med diskriminantanalys. Basta resultatet erholls med hjalp av total cellhalt, som klassificerade $82.9 \%$ av alla juverdelsproven korrekt med avseende på bakterieforekomst. Differentierad cellhalt gav samre resultat både vid klassificerıng av infekterade och icke infekterade juverdelar och vid klassificering av juverdelar med hog- respektiva lågpatogena bakterier. Kombinationen av total och differentierad cellhalt okade inte proportionen korrekt klassificerade juverdelar namnvart, jamfort med vad som erholls med enbart total cellhalt. En okning i proportionen korrekt klassificerade juverdelar, framforallt av antalet korrekt klassificerade infekterade juverdelar, erholls nar man tog hansyn till systematiska faktorer såsom laktationsnummer, laktationsstadium och sasong.

(Recelved February 6, 1989; accepted March 3, 1989).

Reprınts may be requested from: Ulf Emanuelson, Swedısh Associatıon for Livestock Breeding and Productıon, S-631 84 Eskılstuna, Sweden. 
